\title{
„INNOŚĆ DRAŻNI JEDNAKOWOŚĆ"»1 - KILKA UWAG O PROBLEMATYCE DYSKRYMINACJI OSÓB LGBT ZE SZCZEGÓLNYM UWZGLĘDNIENIEM PRZEPISÓW KODEKSU KARNEGO
}

\section{WPROWADZENIE}

Problematyka nietolerancji jest jednym z węzłowych problemów XXI w. W każdym aspekcie ludzkiego życia spotykamy się z dyskryminacją powodowaną różnymi przesłankami: płcia, rasa, wyznawaną religia, czy wreszcie orientacją seksualna. Celem artykułu jest zaprezentowanie tematyki braku tolerancji osób o nieheteronormatywnej orientacji seksualnej oraz odpowiedź na pytanie: czy przyjęte przez polskiego ustawodawcę regulacje prawne zapewniaja dostateczną ochronę przed dyskryminacją mniejszościom seksualnym? W tym celu przeanalizowano raporty organizacji pozarządowych, zapoznano się z dostępnymi publikacjami naukowymi oraz dokonano przeglądu wybranych uregulowań prawnych o charakterze międzynarodowym, a następnie wskazano na uregulowania prawnokarne na gruncie przepisów Kodeksu karnego z 1997 r. W pracy zwrócono także uwagę na aspekt historyczny analizowanego problemu i ewolucję zagadnienia dyskryminacji osób nieheteroseksulanych.

Prace badawcze prowadzone w różnych częściach świata wykazują że odsetek homoseksualnych osób w każdej populacji jest do siebie zbliżony i wynosi ok. $5 \%$ w zależności od sposobu przeprowadzania badania ${ }^{2}$. Według szacunków organizacji pozarządowej LAMBDA ${ }^{3}$ w Polsce jest ok. 2 mln takich osób. „Odmienna” orientacja często jest powodem dyskryminacji, prześladowań i nękania.

Punktem wyjścia przedmiotowych rozważań jest stwierdzenie, że wszyscy ludzie rodzą się wolni i równi wobec prawa i nie powinni być dyskryminowani z uwagi na jakiekolwiek cechy ich różnicujace. Pomimo widocznej zmiany na arenie międzynarodowej, majacej na celu zapewnienie poszanowania praw mniejszości seksualnych - w Polsce nadal brakuje skutecznych mechanizmów,

1 Stachura (1987): 388.

2 Rogowska (2005): 35.

${ }^{3}$ LAMBDA - organizacja pozarządowa pomagająca osobom, które znalazły się w trudnej sytuacji życiowej z uwagi na orientację seksualną i tożsamość płciową. Tekst dostępny na: <http:// lambdawarszawa.org/lambdawarszawa/o-nas/o-lambdzie-warszawa/> [dostęp: 27.09.2018]. 
które zapewniłyby należytą ochronę prawną ofiarom homofobicznych przestępstw z nienawiści.

Przeprowadzona analiza prowadzi do wniosku, że przepisy polskiego Kodeksu karnego są niedostosowane do obecnych realiów i wymagają stosownej nowelizacji. Zapewniają bowiem uprzywilejowane traktowanie osób heteroseksualnych przed osobami innej orientacji. W końcowej części pracy aprobująco odniesiono się do zgłaszanych od kilku lat przez liczne organizacje pozarządowe postulatów de lege ferenda, które przyczyniłyby się do zapewnienia skuteczniejszej ochrony prawnokarnej osób LGBT.

\section{PROBLEMATYKA DYSKRYMINACJI MNIEJSZOŚCI SEKSUALNYCH}

Prawa człowieka sa prawami niezbywalnymi, przynależnymi każdej istocie ludzkiej. Mają one uniwersalny charakter i należą do powszechnych praw moralnych o podstawowym charakterze ${ }^{4}$. Wszyscy ludzie sa równi wobec prawa i nie może być przyzwolenia na dyskryminację z uwagi na posiadane cechy, takie jak: pochodzenie, płeć, wyznanie, poglądy polityczne, czy wreszcie orientację seksualną ${ }^{5}$ i tożsamość płciowa ${ }^{6}$. Słusznie stwierdza Martin Salm, że pozbawienie pewnych ludzi praw człowieka nie jest jedynie problemem dla tych napiętnowanych grup, ale stanowi atak na godność każdego człowieka ${ }^{7}$. Za przyjęciem takiego punktu widzenia przemawia przekonanie o równości wszystkich ludzi i niezbywalności praw im przysługujących.

Mniejszości seksualne funkcjonują w każdym społeczeństwie. Dla ich zdefiniowania używa się skrótu LGBT8, określanego mianem „terminu parasola”, pozwalającego na objęcie nim osób o wspólnych dylematach z uwagi na położenie społeczne, jednakowe problemy i interesy ${ }^{9}$. Bardzo często grupa ta do-

${ }^{4}$ Tekst dostępny na: <http://www.hfhr.pl/wp-content/uploads/2016/02/WiktorOsiatynskiWprowadzenieDoPojeciaPrawCzlowieka.pdf> [dostęp: 27.09.2018].

${ }^{5}$ Jak wskazują Corrêa i Muntarbhotn (2009): 23. Orientacja seksualna - to zdolność każdej osoby do rozwinięcia głębokiego uczuciowego, emocjonalnego i seksualnego pociagu oraz intymnych i seksualnych związków z osobami innej płci lub tej samej płci lub różnych płci.

${ }^{6}$ Jak wskazują Corrêa i Muntarbhotn (2009): 23. Tożsamość płciowa - to głęboko odczuwane wewnętrzne i indywidualne doświadczenie płci społecznej, która może lub nie odpowiadać płci określonej przy urodzeniu, włączając w to osobiste odczucie własnej cielesności (które może prowadzić do modyfikacji wyglądu zewnętrznego lub biologicznych funkcji metodami medycznymi, chirurgicznymi lub innymi) i inne formy wyrażania własnej płciowości przez ubiór, mowę czy sposób zachowania.

7 Salm (2009): 9.

8 Jabłońska, Knut (2012): 22-23. Wskazują że skrót ten pochodzi od słów: lesbijki, geje, osoby biseksualne, transpłciowe. Czasami do tego pojęcia dodaje się także osoby queer (,osoba, która nie chcac być postrzegana przez pryzmat [...] pojęć, takich jak płeć czy orientacja seksualna, unika własnej identyfikacji w ramach takich kategorii jak homoseksualnośćl heteroseksualność czy kobiecośćl męskość) oraz osoby interseksualne (osoby posiadające narządy płciowe żeńskie i męskie"), wówczas używa się skrótu LGBTQI. Niekiedy używa się także skrótu LGBTA, gdzie „A” oznacza osoby aseksualne.

${ }^{9}$ Jabłońska, Knut (2012): 22. 
świadcza różnego rodzaju prześladowań, nękania czy szykanowania powodowanego przynależnością do tzw. nieheteronormatywnej orientacji seksualnej. Walka z prześladowaniami, uprzedzeniami i przemoca jest jednym z głównych aspektów batalii o prawa człowieka. Punktem wyjścia wszelkich rozważań jest wyjaśnienie znaczenia terminu „dyskryminacja”, a następnie zaprezentowanie w tym kontekście sytuacji prawnej osób LGBT.

Podręcznik psychologii stwierdza zatem, że dyskryminacja „pojawia się, gdy wskutek uprzedzeń członkowie jakiejś grupy społecznej są traktowani inaczej, choć sytuacja tego nie uzasadnia"10. Z kolei według słownika psychologii to „prześladowanie, upośledzenie, szykanowanie członków jakiejś grupy (rasowej, wyznaniowej, klasowej itd.), którego powodem jest ich przynależność do owej grupy. To działania, których celem jest pozbawienie dyskryminowanych osób praw i korzyści przysługujących każdemu człowiekowi”11. Z kolei Katarzyna Bojarska dyskryminacją nazywa „świadome lub nieświadome niesprawiedliwe traktowanie osób ze względu na ich rzeczywista lub domniemaną przynależność grupową [...] polegające na utrudnianiu równego i sprawiedliwego dostępu do przysługujących im praw, przywilejów i zasobów społecznych"12. Definicje te posiadają zatem elementy wspólne, jak przynależność do określonej grupy, która wyróżnia się pewnymi cechami, nietypowymi dla reszty społeczeństwa. Ta „inność” jest powodem nierównego traktowania i uprzedzeń. Definicja dyskryminacji ze względu na tożsamość płciową i orientację seksualną znalazła odzwierciedlenie w zasadzie 2 Yogyakarty $^{13}$, zgodnie z którą to „wszelkie zróżnicowanie, wyłączenie, ograniczenie, lub uprzywilejowanie na podstawie orientacji seksualnej lub tożsamości płciowej, które ma na celu lub skutkuje unieważnieniem lub osłabieniem równości wobec prawa lub równej ochrony prawnej, lub uznania wszystkich praw człowieka w równy sposób. Dyskryminacja ze względu na orientację seksualną lub tożsamość płciową może być, i zwyczajowo jest, związana z dyskryminacją na innej podstawie, takiej jak płeć, rasa, religia, niepełnosprawność, status zdrowotny czy ekonomiczny"14. Dyskryminacja może występować w postaci pośredniej lub bezpośredniej. W przypadku dyskryminacji bezpośredniej „osobę traktuje się mniej przychylnie, niż traktuje się, traktowano lub traktowano by inną osobę, w porównywalnej sytuacji” ${ }^{15}$ z takich przyczyn, jak: religia, przekonania, wiek, niepełnosprawność lub orientacja seksualna ${ }^{16}$. Natomiast dyskryminacja pośrednia występuje, gdy przepis, kryterium lub pozornie neutralna praktyka mogą doprowadzić do szczególnie niekorzystnej sytuacji dla osób danej religii lub przekonań, wieku, niepełnosprawności lub orientacji seksualnej,

${ }^{10}$ Ciccarelli, White (2016): 491.

11 Siuta (2009): 68.

12 Bojarska (2005): 7.

13 Dokument poświęcony problematyce ochrony międzynarodowej mniejszości seksualnej.

14 Remin (2009): 27-28.

15 Art. 2 ust. 2a dyrektywy Rady 2000/78/WE z 27 listopada 2000 r. ustanawiającej ogólne warunki ramowe równego traktowania w zakresie zatrudnienia i pracy, Dz. Urz. WE L 303 z 2 grudnia 2000 r. (dalej jako: dyrektywa Rady 2000/78/WE).

16 Art. 2 ust. 2 b dyrektywy Rady 2000/78/WE. 
w stosunku do innych osób, chyba że taki przepis, kryterium lub praktyka sa obiektywnie uzasadnione zgodnym z prawem celem, a środki mające służyć osiągnięciu tego celu są właściwe i konieczne ${ }^{17}$.

Dyskryminacja przyjmuje najczęściej postać agresji werbalnej (nierzadko w formie szantażu albo groźby) lub fizycznej w postaci naruszenia nietykalności cielesnej. Może także przybrać postać tzw. dyskryminacji instytucjonalnej, która występuje wówczas, gdy organy państwowe lub przepisy prawne lepiej traktują osoby heteroseksualne niż osoby o orientacji odmiennej ${ }^{18}$. W psychologii występuje pojęcie społecznej opresji, interpretowanej jako systematyczne i niesprawiedliwe ograniczanie praw oraz wolności określonej grupy ludzi przez grupę dominująca w społeczeństwie ${ }^{19}$. Opresja społeczna przejawia się poprzez heteroseksizm ${ }^{20}$, heteronormatywność ${ }^{21}$ oraz homofobię ${ }^{22}$.

\section{SKUTKI MOWY NIENAWIŚCI}

Stereotypy, brak tolerancji i uwrażliwienia na problemy drugiego człowieka bardzo często znajdują swoje ujście w mowie nienawiści, której skutki moga być bardzo dotkliwe dla osób będących przedmiotem ataku. Powoduja ogromne spustoszenie w psychice ofiary, potęgują uczucie zagrożenia, braku elementarnego poczucia bezpieczeństwa, czy wreszcie obniżenia własnej wartości. Poczucie wyalienowania, beznadziejności i braku perspektyw na poprawę sytuacji niejednokrotnie są przyczyną depresji ${ }^{23}$, a nawet myśli samobójczych. Na taki stan rzeczy wskazują wyniki raportu dotyczącego sytuacji społecznej osób LGBTA ${ }^{24}$ w Polsce. Wskazano w nim związek pomiędzy pogorszeniem się zdrowia psychicznego a doświadczaniem przemocy fizycznej motywowanej nienawiścia, której „nasilenie związane było z większym nasileniem symptomów depresji, częstszymi myślami samobójczymi, niższą samoocena i mniejszym zadowoleniem z życia u osób LGBT"'25.

Wynika z tego dobitny wiosek, że większość osób o nieheteronormatywnej orientacji przejawia przynajmniej łagodne objawy depresji, a co szczególnie

17 Art. 2 ust. 2b dyrektywy Rady 2000/78/WE.

18 Świerszcz (2011): 43.

19 Bojarska (2007): 273.

${ }^{20}$ Przeświadczenie, że heteroseksualność jest bardziej wartościowa niż homoseksualność i biseksualność.

${ }^{21}$ Bojarska (2007): 274 („Kierowanie się w kontaktach społecznych, normach społecznych i formalnoprawnych, wszechobecnym, odgórnym założeniem, że wszyscy ludzie są heteroseksualni. Założenie to obowiązuje, póki [...] wyraźnie nie zostanie stwierdzone, że w danym przypadku jest inaczej").

22 To jawna niechęć w stosunku do osób LGBT.

23 Świder, Winiewski (2017): 65-66. Według wspomnianego już raportu u 28,4\% respondentów występowały poważne objawy depresji. Najsilniejsze symptomy choroby wstępują zazwyczaj u osób transpłciowych, aseksualnych i kobiet biseksualnych. Najmniejsze zaś odnotowuje się w grupie gejów i mężczyzn o skłonnościach biseksualnych.

${ }^{24}$ Skrót od lesbijki, geje, osoby biseksualne, osoby transpłciowe, osoby aseksualne.

25 Świder, Winiewski (2017): 82. 
niepokojące - odsetek osób z poważnymi symptomami tej choroby jest ponad pięć razy większy niż w populacji ogólnej ${ }^{26}$. Szczególnie przykry i wyjątkowo trudny do przezwyciężenia jest problem dyskryminacji wśród grupy rówieśniczej, która jest szczególnie istotna w środowisku nastolatków. Mowa nienawiści w stosunku do młodzieży szkolnej utożsamiajacej się z LGBT jest wszechobecna i niestety często akceptowalna. Młode osoby poszukujące dopiero własnej tożsamości z wielkim trudem akceptują swój ewentualny homoseksualizm, biseksualizm lub transseksualizm ${ }^{27}$. Znaczna część incydentów przemocowych występuje w szkole, a sprawcami są często koledzy i koleżanki ze szkolnej ławy ${ }^{28}$. Presja, z jaką się stykają młodzi ludzie, często nie spotyka się z żadnymi reakcjami ze strony osób bądź instytucji do tego powołanych. W tego typu przypadkach istnieje bardzo duży margines „ciemnej liczby” przestępstw, które nigdy nie zostały zgłoszone organom ścigania. Przyczyny takiego stanu rzeczy są złożone, wśród najważniejszych wymienić można: obawę przed ich bagatelizowaniem, strach przed napiętnowaniem, ośmieszeniem, wtórną wiktymizacja, ale także brak wiary w skuteczność organów ścigania.

Przełomem w takim postępowaniu może okazać się precedensowy, pierwszy w historii polskiego sądownictwa wyrok, przeciwko szkole za brak przeciwdziałania homofobii wśród uczniów ${ }^{29}$. W przedmiotowej sprawie homoseksualny uczeń, mówiący wprost o swojej orientacji seksualnej, był prześladowany i dręczony przez swoich szkolnych kolegów. Początkowe wyzwiska z czasem przerodziły się w agresję fizyczną i skutkowały poważnymi konsekwencjami u ofiary, objawiającymi się w odczuwaniu strachu, przygnębienia, opuszczania lekcji celem uniknięcia wychodzenia ze szkoły razem z innymi uczniami. Sąd przyznał rację skarżącemu, uznając naruszenie jego dóbr osobistych i podkreślając przy tym ich szczególny charakter i konieczność dążenia do „ich ochrony w każdym przypadku, w którym odniesiony w nich uszczerbek znajduje potwierdzenie nie tylko w odczuciu samego zainteresowanego, ale i w zobiektywizowanej ocenie zewnętrznej”. Wobec bagatelizowania problemu i bezczynności szkoły Sąd zobowiązał ją do opublikowania na stronie internetowej placówki komunikatu z przeprosinami ${ }^{30}$. Wyrok Sądu Apelacyjnego w Warszawie jest bezsprzecznie krokiem milowym w tego typu sprawach i z pewnością przyczyni się do zwiększenia częstotliwości zgłaszania podobnych przypadków.

\section{WALKA Z HOMOSEKSUALIZMEM}

Dyskryminacja osób nieheteroseksualnych nie jest problemem nowym, a walkę z tego typu przypadkami rozpoczęto już w XIX w. Depenalizacja homoseksualizmu następowała stopniowo, zapoczątkował ją Kodeks Napoleona

\footnotetext{
26 Świder, Winiewski (2017): 132.

27 Ciccarelli, White (2009): 395.

28 Świder, Winiewski (2017): 134.

29 Wyrok SA w Warszawie z 17 listopada 2017 r., I ACa 1372/16, Lex nr 2516062.

${ }^{30}$ Wyrok SA w Warszawie z 17 listopada 2017 r., I ACa 1372/16, Lex nr 2516062.
} 
z 1804 r., następnie w 1813 r. w Bawarii zrezygnowano z karania tego typu związków, a niedługo potem w ich ślad poszedł rząd Hanoweru ${ }^{31}$. Dojście do władzy Hitlera i wybuch II wojny światowej zapoczątkowały zmianę kursu i stopniową eliminację osób homoseksualnych ze społeczeństwa. Znamiennym przykładem dyskryminacji był $\S 175$ niemieckiego kodeksu karnego, zgodnie z którym „Nierząd przeciwny naturze popełniony przez osoby płci męskiej ${ }^{32}$ pomiędzy sobą albo przez ludzi ze zwierzętami, ulegnie karze więzienia; można także orzec utratę praw czci obywatelskiej”33. Rozpoczęto systematyczna walkę z homoseksualistami, którzy zsyłani byli do obozów zagłady, gdzie dokonywano ich systematycznej eksterminacji. Celem odróżnienia tej grupy skazańców od pozostałych więźniów oznaczano ich symbolem różowego trójkąta. Znajdowali się oni na samym dole więziennej hierarchii i byli wykorzystywani do najcięższych prac. Zresztą odsetek śmiertelności wśród tej grupy więźniów był jednym z najwyższych.

W dzisiejszych czasach w takich krajach, jak: Iran, Jemen, Arabia Saudyjska, Sudan, niektórych regionach Somalii i Nigerii, za utrzymywanie stosunków seksualnych grozi kara śmierci. Nie tak dawno do światowej opinii publicznej przeniknęła informacja, że w Czeczeni powstają obozy dla homoseksualnych mężczyzn, w których dochodzi do tortur i zabijania więźniów ${ }^{34}$.

\section{PRAWA OSÓB HOMOSEKSUALNYCH W WYBRANYCH UREGULOWANIACH MIĘDZYNARODOWYCH}

Prawo do ochrony przed dyskryminacją znajduje odzwierciedlenie w uregulowaniach zarówno na poziomie krajowym, jak i międzynarodowym ${ }^{35}$. Przykładowo art. 2 ust. 2 Międzynarodowego pakt praw obywatelskich i politycznych stanowi: „Każde z Państw Stron zobowiąuje się przestrzegać i zapewnić wszystkim osobom, które znajdują się na jego terytorium i podlegają jego jurysdykcji, prawa uznane w niniejszym Pakcie, bez względu na jakiekolwiek różnice, takie jak: rasa, kolor skóry, płeć, język, religia, poglądy polityczne i inne, pochodzenie narodowe lub społeczne, sytuacja majątkowa, urodzenie

31 Biedroń (2012): 14.

32 Warto w tym miejscu podkreślić, że wspomniany przepis odnosił się jedynie do „osób płci męskiej”. Nie oznacza to jednak, że kontakty homoseksualne pomiędzy kobietami były akceptowalne, ale były one rzadsze i brak jest oficjalnych statystyk na ten temat.

${ }^{33}$ Kodeks karny Rzeszy Niemieckiej z dnia 15 maja 1871 r. z późniejszymi zmianami i uzupełnieniami po rok 1918 wraz z ustawą wprowadczą do kodeksu karnego dla związku północno-niemieckiego (Rzeszy niemieckiej) z dnia 31 maja 1870 r., [w:] Ustawy byłej dzielnicy pruskiej, przekład urzędowy Departamentu Byłej Dzielnicy Pruskiej, t. 1, Poznań 1920: 77.

${ }_{34}$ Tekst dostępny na: <http://www.newsweek.pl/swiat/spoleczenstwo/homoseksualisci-w-czeczenii-obozy-koncentracyjne-dla-gejow, artykuly,408719,1.html> [dostęp: 20.09.2018].

35 Wśród aktów prawa międzynarodowego należy zwrócić uwagę na: Międzynarodową konwencję w sprawie likwidacji wszelkich form dyskryminacji rasowej (Dz. U. 1969, Nr 25, poz. 187 z załącznikami) czy Konwencję w sprawie likwidacji wszelkich form dyskryminacji kobiet (Dz. U. 1982, Nr 10, poz. 71 z załącznikami). 
lub jakiekolwiek inne okoliczności” ${ }^{36}$. O zakazie dyskryminacji wspomina także art. 2 ust. 2 Międzynarodowy pakt praw gospodarczych, społecznych i kulturalnych: „Państwa Strony niniejszego Paktu zobowiązuja się zagwarantować wykonywanie praw wymienionych w niniejszym Pakcie bez żadnej dyskryminacji ze względu na rasę, kolor skóry, płeć, język, religię, poglądy polityczne lub inne, pochodzenie narodowe lub społeczne, sytuację majątkowa, urodzenie lub jakiekolwiek inne okoliczności” ${ }^{37}$. Przepisy antydyskryminacyjne znalazły się także w art. 14 Konwencji o ochronie praw człowieka i podstawowych wolności: „Korzystanie z praw i wolności [...] powinno być zapewnione bez dyskryminacji wynikającej z takich powodów, jak płeć, rasa, kolor skóry, język, religia, przekonania polityczne i inne, pochodzenie narodowe lub społeczne, przynależność do mniejszości narodowej, majątek, urodzenie, bądź z jakichkolwiek innych przyczyn"38. Pomimo szeregu uregulowań zakazujących dyskryminacji z jakiejkolwiek przyczyny, a więc także z uwagi na orientację seksualną lub tożsamość płciową - osoby przynależące do społeczności LGBT są często obiektem prześladowań, szykan i dyskryminacji zarówno w życiu prywatnym, jak i zawodowym, zreszta - jak już wcześniej wspomniano - w niektórych krajach grożą im prześladowania, a niekiedy także kara śmierci. Przykładowo art. 204 nikaraguańskiego kodeksu karnego stanowi, że: „każdy, kto nakłania, promuje, propaguje lub praktykuje w skandalicznej formie stosunki seksualne między osobami tej samej płci, popełnia przestępstwo sodomii i podlega karze od jednego do trzech lat więzienia" ${ }^{39}$. W Ugandzie natomiast w 2014 r. doszło do zaostrzenia przepisów penalizujących stosunki homoseksualne $e^{40}$. Podobnie sytuacja wygląda w Kamerunie ${ }^{41}$.

Ze względu na powtarzające się w ostatnich latach różne przypadki naruszania praw człowieka z uwagi na orientację seksualną lub tożsamość płciową w 2005 r. Parlament Europejski przyjął rozporządzenie potępiające homofobię i dyskryminację z tych właśnie powodów ${ }^{42}$. Na problem dyskryminacji osób nieheteronormatywnych zwrócono też uwagę w 2008 r. w trakcie obrad Zgromadzenia Ogólnego ONZ, gdzie przedstawiono oświadczenie ${ }^{43}$, w którym wzywano do całkowitej dekryminalizacji homoseksualizmu. Jednakże na skutek zaostrzenia w niektórych krajach przepisów penalizujących kontakty homoseksualne Parlament Europejski polecił Agencji Praw Podstawowych ${ }^{44}$

\footnotetext{
${ }^{36}$ Międzynarodowy pakt praw obywatelskich i politycznych, Dz. U. 1977, Nr 38, poz. 167 z załącznikami (dalej jako: MPPOiP).

${ }^{37}$ Międzynarodowy pakt praw gospodarczych, społecznych i kulturalnych, Dz. U. 1977, Nr 38, poz. 169 z załącznikami (dalej jako: MPPGSiK).

${ }^{38}$ Konwencja o ochronie praw człowieka i podstawowych wolności, Dz. U. 1993, Nr 61, poz. 284 (dalej jako: EKPC).

${ }^{39}$ Tekst dostępny na: <https://amnesty.org.pl/nikaragua-ostatni-w-ameryce-\%C5\%82aci\%C5\% 84skiej-kodeks-karny-penalizuj\%C4\%85cy-homoseksualizm/> [dostęp: 10.09.2018].

${ }_{40}$ Tekst dostępny na: <https://amnesty.org.pl/prezydent-ugandy-podpisa\%C5\%82-ustaw\% C4\%99-zaostrzaj\%C4\%85c\%C4\%85-kary-za-homoseksualizm/> [dostęp: 10.09.2018].

${ }^{41}$ Więcej na ten temat: Amnesty International (2013).

${ }^{42}$ European Union Agency for Fundamental Rights (2009): 3.

${ }^{43}$ Przygotowane przez Francję i Holandię z poparciem 66 krajów z całego świata.

${ }^{44}$ Dalej jako: Agencja.
} 
zbadanie sytuacji prawnej osób LGBT we wszystkich państwach członkowskich UE ${ }^{45}$. Wynikiem prac Agencji było opracowanie kompleksowego raportu uwzględniającego aspekt społeczny i prawny osób LGBT ${ }^{46}$. W dokumencie zwrócono uwagę na kierunki dyskryminacji, takie jak: zmuszanie do życia w milczeniu i „stawania się niewidzialnymi dla reszty społeczeństwa”, brutalne ataki oraz dyskryminację $\mathrm{w}$ miejscu zamieszkania bądź wykonywania pracy zawodowej ${ }^{47}$. Stworzono rekomendacje dla państw członkowskich UE, których założeniem miało być przyczynienie się do podjęcia zdecydowanych kroków przeciw homofobii oraz dyskryminacji. Ponadto zalecono opracowanie specjalnych mechanizmów gromadzenia danych na wypadek zaistnienia takich zdarzeń oraz wspierania badań naukowych i zachęcania osób dyskryminowanych do zgłaszania takich przypadków ${ }^{48}$.

$\mathrm{Na}$ uwagę zasługuje też Zalecenie Rady Europy z 2010 r. dotyczące konieczności podjęcia działań antydyskryminacyjnych w stosunku do mniejszości seksualnych w państwach członkowskich. W preambule dokumentu stwierdzono, że z uwagi na trwająca przez wieki dyskryminację lesbijek, gejów, osób biseksualnych i transpłciowych konieczne jest podjęcie działań o charakterze szczególnym, których celem będzie zapewnienie przestrzegania praw człowieka ${ }^{49}$. Zwrócono uwagę na orzecznictwo Europejskiego Trybunału Praw Człowieka (ETPC) ${ }^{50}$ oraz podkreślono: „iż dyskryminacja i wyłączenie społeczne spowodowane orientacją seksualną lub tożsamością płciową moga być w najlepszy sposób przezwyciężone poprzez środki skierowane zarówno do tych, którzy doświadczają takiej dyskryminacji i wykluczenia, jak i do społeczeństwa w ogóle" ${ }^{51}$. Sprecyzowano przy tym zalecenia dla państw członkowskich celem poprawy jakości życia osób o orientacji odmiennej od heteroseksualnej i wprowadzono rekomendacje dotyczące: zbadania istnienia właściwych środków prawnych, dokonywania ich stałego przeglądu, monitorowania sytuacji związanych z jakąkolwiek pośrednią lub bezpośrednią dyskryminacją z uwagi na orientację seksualna, zapewnienie, aby środki prawne tego rodzaju zostały wprowadzone i spowodowały poszanowanie praw człowieka osób przynależnych do LGBT, zapewnienia, aby w razie naruszenia praw takich osób miały one dostęp do przysługujących im narzędzi prawnych za pośrednictwem organów krajowych ${ }^{52}$. 28 września 2011 r. Parlament Europejski przyjął re-

\footnotetext{
${ }_{45}$ Tekst dostępny na:<http://fra.europa.eu/sites/default/files/fra_uploads/1757-FRA-FactsheetHomophobia-Study-2010-FS1_PL.pdf> [dostęp: 13.09.2018].

${ }^{46}$ Opracowany dokument spotkał się także z uwagami krytycznymi; tekst dostępny na: $<$ https://www.ordoiuris.pl/wolnosc-sumienia/uwagi-do-dokumentu-agencji-praw-podstawowych-unii-europejskiej-protection-against> [dostęp: 5.10.2018].

${ }^{47}$ Tekst dostępny na:<http://fra.europa.eu/sites/default/files/fra_uploads/1757-FRA-FactsheetHomophobia-Study-2010-FS1_PL.pdf> [dostęp: 13.09.2018].

${ }^{48}$ European Union Agency for Fundamental Rights (2009): 4.

${ }^{49}$ Zalecenie Komitetu Ministrów dla Państw Członkowskich w zakresie środków zwalczania dyskryminacji opartej na orientacji seksualnej lub tożsamości płciowej, CM/Rec(2010)5: 1-3 (dalej jako: Zalecenie CM/Rec(2010)5).

${ }^{50}$ Np. skarga nr 26431/12, skargi 67667/09, 44092/12 i 56717/12, skargi nr 18766/11 i 36030/11.

${ }^{51}$ Zalecenie CM/Rec(2010)5: 3.

${ }^{52}$ Zalecenie CM/Rec(2010)5: 3.
} 
zolucję w sprawie praw człowieka, orientacji seksualnej i tożsamości płciowej w państwach członkowskich Organizacji Narodów Zjednoczonych ${ }^{53}$. Parlament Europejski kolejny zreszta już raz zauważył, że w państwach członkowskich Unii Europejskiej, jak i w krajach trzecich każdego dnia dochodzi do wielu przypadków naruszenia praw człowieka z uwagi na orientację seksualną i tożsamość płciową (lit. B). Podkreślił konieczność zapewnienia poszanowania praw człowieka (lit. C) i konieczność zaangażowania Unii Europejskiej w prace poświęcone poszanowaniu praw osób dyskryminowanych z uwagi na orientację seksualną (lit. E). Wyraził przy tym obawę związaną z licznymi przypadkami pogwałcenia praw człowieka i nagminną dyskryminacja z uwagi na przynależność do mniejszości seksualnej zarówno w Unii Europejskiej, jak i w krajach trzecich (pkt 1). Przypominał, że zestaw narzędzi służących propagowaniu i ochronie wszystkich praw człowieka przysługujacych lesbijkom, gejom, biseksualistom i osobom transgenderowym (LGBT) opracowany przez Grupę Robocza ds. Praw Człowieka Rady Unii Europejskiej wymienia wśród kluczowych priorytetów depenalizację homoseksualizmu na świecie, równość i zasadę niedyskryminacji oraz zapewnienie ochrony obrońcom praw człowieka (pkt 7). Wyraził także ubolewanie, że nie zawsze prawa człowieka, a zwłaszcza prawa lesbijek, gejów i osób transgenderowych są w Unii Europejskiej przestrzegane (pkt 11). Potępił przy tym fakt, że w niektórych krajach członkowskich homoseksualizm, biseksualizm i transseksualizm sa traktowane jak choroby psychiczne, w związku z czym wezwał wszystkie państwa członkowskie do „depsychiatryzacji procesu, jaki przechodzą osoby transseksualne i transgenderowe" (pkt 13). Wezwał do pełnego wyeliminowania tych nierówności (pkt 15), podkreślając przy tym konieczność usunięcia zaburzeń tożsamości płciowej z listy zaburzeń psychicznych i zaburzeń zachowania oraz potrzebę zapewnienia nowej klasyfikacji wolnej od ich patologizowania $(\text { pkt 16) })^{54}$.

Warto w tym miejscu przypomnieć, że zalecenia czy rekomendacje nie mają charakteru prawnie wiążącego, zaliczane są one do tzw. miękkiego prawa międzynarodowego i sa jedynie instrukcjami dla państw członkowskich UE. Niemniej stanowią one ważny krok w dyskusji na temat przestrzegania i poszanowania praw osób dyskryminowanych z uwagi na orientację seksualną lub tożsamość płciową. Sa przejawem zmieniającego się światopoglądu dostosowanego do zmieniających się realiów społecznych i zwracają uwagę na problem dyskryminowanych mniejszości.

Nie można być jednostronnym w ocenach i trzeba pamiętać, że w dużej części krajów istnieją odpowiednie mechanizmy prawne zabezpieczające w mniejszej lub większej skali sferę praw osób LGBT. Należą do nich m.in.: Dania Belgia, Hiszpania, Rumunia, Portugalia, Francja, Holandia, Szwecja oraz

${ }^{53}$ Rezolucja Parlamentu Europejskiego z 28 września 2011 r. w sprawie praw człowieka, orientacji seksualnej i tożsamości płciowej w państwach członkowskich Organizacji Narodów Zjednoczonych, P7_TA(2011)0427.

${ }^{54}$ Do 1991 r. homoseksualizm był przez Światową Organizację Zdrowia uznawany za jednostkę chorobową. 
część Wielkiej Brytanii, a także Niemcy, Estonia, Litwa, Irlandia, Finlandia ${ }^{55}$. Tytułem przykładu można wymienić Holandię w której w latach 2011-2014 przyjęto tzw. Simply Gay - dokument, który w sposób kompleksowy uregulował sytuację prawną osób LGBT. W Szwecji zadaniem agencji rządowej jest natomiast promowanie praw człowieka i zwalczanie instytucjonalizacji heteroseksualności ${ }^{56}$. Wielka Brytania prowadzi natomiast działania mające na celu walkę z jakimikolwiek uprzedzeniami, w tym także powodowanymi orientacją seksualną ${ }^{57}$. Warto też zauważyć, że na początku września 2018 r. Indie wykreśliły ze swojego kodeksu karnego przepisy penalizujące stosunki homoseksualne, które od 1861 r. zagrożone były karną do 10 lat pozbawienia wolności ${ }^{58}$. Są też państwa, takie jak: Polska, Węgry, Luksemburg, Włochy, Bułgaria, Grecja, Malta, Słowacja, Austria, Słowenia, Łotwa, Cypr i Malta, w których osoby te nie znajdują szczególnej ${ }^{59}$ ochrony na podstawie przepisów prawa karnego $0^{60}$.

\section{DYSKRYMINACJA OSÓB LGBT W ŚWIETLE PRZEPISÓW KODEKSU KARNEGO}

Kryminalizacja stosunków homoseksualnych na ziemiach polskich istniała od 1835 r., a więc pod rządami przepisów karnych państw zaborczych. Depenalizacja nastapiła dopiero w Kodeksie karnym z 1932 r. Jednakże nadal sankcjonowano tzw. prostytucje homoseksualna. Artykuł 207 k.k. z 1932 r. stanowił: „Kto z chęci zysku ofiarowuje się osobie tej samej płci do czynu nierządnego podlega karze więzienia do lat 3”. Co ciekawe, Kodeks karny nie penalizował czynów nierządnych pomiędzy osobami płci przeciwnej ${ }^{61}$, jak również prostytucji uprawianej zawodowo dla zysku ${ }^{62}$. Wacław Makowski zauważał przy tym, że Kodeks karny w tego rodzaju sankcjach widział „karygodne pasożytowanie na zboczeniach instynktu płciowego i wyzyskiwanie stanu cho-

55 European Union Agency for Fundamental Rights (2009): 122-125.

56 Tekst dostępny na: <http://fra.europa.eu/sites/default/files/fra_uploads/1757-FRA-Factsheet-Homophobia-Study-2010-FS1_PL.pdf> [dostęp: 6.10.2018].

57 Tekst dostępny na: <http://fra.europa.eu/sites/default/files/fra_uploads/1757-FRA-Factsheet-Homophobia-Study-2010-FS1_PL.pdf> [dostęp: 6.10.2018].

58 Polityka (2018): 11.

59 Używając terminu „szczególna ochrona”, mam na myśli brak przepisów penalizujących za przejawy dyskryminacji z uwagi na orientację seksualną i tożsamość płciową. Takie przypadki sa kwalifikowane na podstawie przepisów ogólnych.

60 European Union Agency for Fundamental Rights (2009): 43.

${ }^{61}$ Chyba że zaistniały szczególne przesłanki, takie jak: art. 203 k.k. - dopuszczenie się czynu nierządnego względem osoby poniżej 15 roku życia lub w stosunku do osoby zupełnie lub częściowo pozbawionej zdolności rozpoznania znaczenia czynu lub pokierowania swoim postępowaniem; art. 204 k.k. - doprowadzenie do poddania się czynowi nierządnemu lub wykonania takiego czynu przy pomocy przemocy, groźby, podstępu; art. 205 - doprowadzenie do poddania się czynowi nierządnemu lub wykonania takiego poprzez nadużycie stosunku zależności lub wyzyskanie krytycznego położenia.

62 Makowski (1933): 477. 
robowego osób [...]”63. Podmiotem tego czynu mogli być mężczyźni w stosunku do mężczyzn i kobiety oferujące takie usługi innym kobietom. Zarówno k.k. z 1969 r., jak i z 1997 r. zrezygnowały z penalizowania tego typu zachowań.

W obecnym stanie prawnym Rzeczpospolitej Polskiej przed dyskryminacją chronia przede wszystkim zapisy Konstytucji z 1997 r. Zgodnie z treścia art. 32 „Ust. 1 Wszyscy są wobec prawa równi. Wszyscy mają prawo do równego traktowania przez władze publiczne. Ust. 2 Nikt nie może być dyskryminowany w życiu politycznym, społecznym lub gospodarczym z jakiejkolwiek przyczyny”. Zakaz dyskryminacji sprecyzowany w Konstytucji ma charakter uniwersalny i odnosi się do każdego człowieka. Nikt nie może zatem być dyskryminowany z jakiejkolwiek przyczyny, a więc też z uwagi na orientację seksualna.

Problematyka dyskryminacji jest bardzo złożona, istnieje społeczne przyzwolenie na dokonywanie aktów przemocy motywowanych różnymi pobudkami, czy to na tle narodowościowym, wyznaniowym, czy homofobicznym. W sferze prawa karnego brak jednak ściśle sprecyzowanych przepisów, które odnosiłyby się stricte do dyskryminacji z uwagi na przynależność do określonej mniejszości seksualnej. Polski system prawny reguluje problematykę przestępstw z nienawiści motywowanych takimi przesłankami, jak: przynależność narodowa, etniczna, rasowa, polityczna, wyznaniowa czy bezwyznaniowość (art. 119 k.k.). Nie wspomina jednak o dyskryminacji z powodu orientacji seksualnej czy tożsamości płciowej. Warto w tym miejscu zacytować treść raportu Amnesty International odnoszącego się do problematyki dyskryminacji: „Fakt odmiennego traktowania przez prawo polskie przestępstw z nienawiści popełnianych przeciwko określonym grupom sam w sobie stanowi dyskryminację, a to ze względu na brak obiektywnego uzasadnienia dla wprowadzenia takiego rozróżnienia" ${ }^{6}$. Taki stan rzeczy powoduje, że osoby narażone na dyskryminację z uwagi na swoją orientację są zmuszone do korzystania z ochrony prawnej na zasadach ogólnych. Trzeba bowiem zaznaczyć, że różne formy dyskryminacji mają swoje specyficzne cechy i wymagają szczególnego ustosunkowania się do tego zagadnienia ${ }^{65}$. Ogólne podejście do problemu powoduje trudności dowodowe, ale także ustala hierarchię ofiar, skutkuje to także różnicami w ściganiu i karaniu sprawców ${ }^{66}$. Luka prawna w tym względzie musi zostać wypełniona, gdyż prawo karne powinno nadążać za duchem czasu i zmieniajacych się realiów społecznych.

Organizacje pozarządowe od lat apelują o wprowadzenie do kodeksu karnego przepisów majacych na celu zapewnienie ochrony przed dyskryminacja motywowaną homofobią ${ }^{67}$. Akceptując zgłaszane postulaty, uważam, że zasadne byłoby wprowadzenie zmian w postaci poszerzenia katalogu przesłanek art. 119 k.k., art. 256 k.k. i art. 257 k.k. W projekcie kodeksu karnego z 2009 r.

${ }^{63}$ Makowski (1933): 477.

${ }^{64}$ Amnesty International (2015): 5.

${ }^{65}$ Wieruszewski (2009): 20.

66 Wasik, Godzisz (2016): 7.

${ }^{67} \mathrm{Na}$ ten problem zwracały uwagę Helsińska Fundacja Praw Człowieka, Amnesty International i Kampania przeciw Homofobii. 
proponowano nowelizację art. 119 k.k. w postaci dodania znamienia dotyczącego stosowania przemocy lub groźby bezprawnej z uwagi na płeć, tożsamość płciowa, niepełnosprawność bądź orientację seksualną ${ }^{68}$. Ponadto zaproponowano zmianę treści przepisu art. $256 \mathrm{k}$.k. przez rozszerzenie znamion w postaci nawoływania do nienawiści z uwagi na płeć, tożsamość płciowa, wiek, niepełnosprawność, orientację seksualną oraz dodanie do treści przepisu art. $257 \mathrm{k} . \mathrm{k}$. identycznych do powyższych przesłanek ${ }^{69}$. Odnosząc się do proponowanych zmian, Eleonora Zielińska słusznie zauważyła, że Polska jest społeczeństwem mało tolerancyjnym, atmosfera wrogości w stosunku do osób „odmiennych” przyczynia się do ich marginalizacji i społecznego wykluczenia ${ }^{70}$.

Aprobując zgłoszone postulaty de lege ferenda, uważam, że proponowane zmiany skutecznie przyczyniłyby się do poszerzenia zakresu ochrony osób dyskryminowanych z uwagi na orientację seksualną lub tożsamość płciowa. Sprawiłyby, że przepisy prawa karnego przystawałyby do obecnych realiów i podążałyby za standardami i trendami międzynarodowymi. Dzisiejszy kształt kodeksu karnego nie zapewnia wystarczającej ochrony przed homofobiczna mową nienawiści. Potwierdzeniem takiego stanowiska jest wyrok Sądu Rejonowego we Wrocławiu z 5 czerwca 2015 r., w którym doszło do skazania mężczyzny za używanie słów: „pedał” oraz „zboczeniec”, skierowanych do osoby, która przeszła operację zmiany płci ${ }^{71}$. W uzasadnieniu wyroku Sąd stwierdził: „Nie budzi wątpliwości, że określenia oznaczające mężczyznę o odmiennej orientacji seksualnej oraz człowieka o odmiennych, dziwacznych lub moralnie (czy też prawnie) nagannych upodobaniach, zachowaniach stanowią określenia znieważające, a zwłaszcza jeśli są skierowane do osoby, która poddała się operacji zmiany płci. Nie da się zaprzeczyć, że sa to zwroty zabarwione pejoratywnie, powszechnie uznane w społeczeństwie lub w danym regionie jako wyrażające pogardę dla człowieka”. W wyroku Sąd uznał, że przedmiotowe zachowanie wypełniło znamiona przestępstwa znieważenia (art. $216 \S 1$ k.k.). Taki stan rzeczy podyktowany jest zamkniętym katalogiem osób podlegających ochronie na mocy przepisu art. $257 \mathrm{k} . \mathrm{k}$. Przepis ten nie wymienia wśród grupy chronionej osób dyskryminowanych z uwagi na orientację seksualna i tożsamość płciową. Różnica jest zatem istotna, z uwagi na motywację sprawcy, ale także wysokość zagrożenia karnego oraz tryb ścigania. Przepis art. 216 $\S 1$ k.k. przewiduje bowiem sankcję w postaci kary grzywny, albo kary ograniczenia wolności, podczas gdy przepis art. $257 \mathrm{k} . \mathrm{k}$. daje możliwość wymierzenia kary pozbawienia wolności do lat 3. Ponadto należy zgodzić się z Dagmara Gruszecka, która stwierdza, że kwalifikując zachowanie jako zniewagę, należy pamiętać o związku pomiędzy określonym postępowaniem a motywacją o charakterze dyskryminacyjnym, a takiej w treści przepisu art. $216-$ brak $^{72}$. Kolejną istotną różnica jest wspomniany już tryb ścigania. Występek z art. 216

${ }^{68}$ Projekt ustawy o zmianie ustawy - Kodeks karny, [w:] G. Czarnecki, Raport o homofobicznej mowie nienawiści w Polsce, Warszawa 2009: 76.

${ }^{69}$ Projekt ustawy o zmianie ustawy - Kodeks karny (2009): 76.

70 Zielińska (2009): 77.

71 Wyrok SR we Wrocławiu z 5 czerwca 2015 r., XII K 458/14.

72 Gruszecka (2014): 920. 
$\S 1$ k.k. ścigany jest z oskarżenia prywatnego, natomiast czyn z art. 257 k.k. w trybie publicznoskargowym. Rozszerzenie znamion wspomnianych na wstępie przepisów zapewniłoby skuteczniejszą ochronę prawną pokrzywdzonym, ale także mogłyby zmienić sposób ich postrzegania przez społeczeństwo i skutecznie zapewnić respektowanie ich praw.

\section{WNIOSKI KOŃCOWE}

Jak pisał Edward Stachura: „inność drażni jednakowość”. Ludzie, którzy wyróżniają się z tych czy innych powodów, zawsze narażeni są na dyskryminację. Osoby LGBT od zawsze były poddawane różnego rodzaju presji społecznej. Warto zauważyć, że do 1991 r. homoseksualizm znajdował się na liście chorób psychicznych Światowej Organizacji Zdrowia. Mimo uznania homoseksualizmu i biseksualizmu za równoprawna, obok heteroseksualizmu, orientację seksualna - stosunki homoseksualne sa nadal penalizowane w niektórych państwach. Szczególnie jest to widoczne w krajach afrykańskich i azjatyckich.

W Polsce nadal brakuje skutecznych narzędzi w sferze prawa karnego, które zapewniałyby efektywna ochronę przed dyskryminacją z uwagi orientację seksualną lub tożsamość płciową. Zmiana światopoglądowa i zmiana nastawienia do „inności” powinna odbywać się od najmłodszych lat. Słowem klucz jest tolerancja, która powinna być wpajana od wczesnego dzieciństwa. Zasadne byłoby wprowadzenie obowiązkowych zajęć szkolnych, podczas których uczono by empatii i poszanowania praw innych ludzi, bez względu na ich kolor skóry, odmienność kulturowa, wyznanie, niepełnosprawność, orientację seksualną czy tożsamość płciową. Nieprzeceniona w tym względzie jest rola organizacji pozarządowych promujących otwarte podejście do drugiego człowieka i uwrażliwianie na potrzeby innych. Prawo powinno wszystkich ludzi traktować jednakowo, zapewnić im równe szanse i równe prawa bez względu na cechy ich determinujące.

Katarzyna Czeszejko-Sochacka

Uniwersytet Rzeszowski

kczeszejko@ur.edu.pl

https://orcid.org/0000-0001-7978-1687

Amnesty International (2013). Making Love a Crime: Criminalization of Same-Sex Conduct in Sub-Saharan Africa. United Kingdom.

Amnesty International (2015). Dotknięci przez nienawiść, zapomniani przez prawo. Brak spójnego systemu zwalczania przestępstw z nienawiści w Polsce. United Kingdom.

Biedroń, R. (2012). Nazistowskie prześladowania osób homoseksualnych, [w:] K. Remin (red.), Różowe trójkąty. Zbrodnie nazistów na osobach homoseksualnych w kontekście edukacji antydyskryminacyjnej. Warszawa: 14-53.

Bojarska, K. (2005). Psychologiczne i społeczne uwarunkowania stereotypów, uprzedzeń i dyskryminacji, [w:] M. Pawlęga, Przeciwdziałanie dyskryminacji. Pakiet edukacyjny dla trenerów i trenerek. Warszawa: 7-21. 
Bojarska, K (2007). Badania pilotażowe: osoby homo- i biseksualne wobec hetero seksizmu, heteronormatywności i homofobii. Społeczna opresja jako wyznacznik powtarzalnych wzorców reakcji obronnych, [w:] G. Chojnacka-Szawiłowska, B. Pastwa-Wojciechowska, Kliniczne i sadowo-penitencjarne aspekty funkcjonowania człowieka. Kraków: 273-280.

Ciccarelli, S.K., White, J.N. (2016). Psychologia. Tłum. A. Bukowski, J. Środa. Poznań.

Corrêa, S.O., Muntarbhotn, V. (2009). Wprowadzenie do Zasad Yogyakarty, [w:] K. Remin (red.), Zasady Yogyakarty. Zasady stosowania międzynarodowego prawa praw człowieka w stosunku do orientacji seksualnej oraz tożsamości płciowej. Warszawa: 7-8.

European Union Agency for Fundamental Rights (2009). Homofobia i dyskryminacja z powodu orientacji seksualnej i tożsamości płciowej państwach członkowskich UE. Część 2: Sytuacja społeczna. Wiedeń.

Gruszecka, D. (2014). Przestępstwa przeciwko porządkowi publicznemu, [w:] J. Giezek, Kodeks karny. Część szczególna. Komentarz. Warszawa: 880-976.

Jabłońska, Z., Knut, P. (2012). LGBT. Prawa osób LGBT w Polsce. Raport z badań nad wdrażaniem Zalecenia CM/Rec (1010)5 Komitetu Ministrów Rady Europy dla Państw Członkowskich w zakresie środków zwalczania dyskryminacji opartej na orientacji seksualnej lub tożsamości płciowej. Warszawa.

Kampania Przeciw Homofobii (2012). Prawa osób LGBT w Polsce. Raport z badań nad wdrażaniem Zalecenia CM/Rec 2010(5) Komitetu Ministrów Rady Europy dla Państw Członkowskich w zakresie środków zwalczania dyskryminacji opartej na orientacji seksualnej lub tożsamości płciowej. Warszawa.

Makowski, W. (1933). Kodeks karny 1932. Komentarz. Warszawa.

Remin, K. (2009). Zasady Yogyakarty. Zasady stosowania międzynarodowego prawa praw człowieka w stosunku do orientacji seksualnej oraz tożsamości płciowej. Warszawa.

Rogowska, A. (2005). Dyskryminacja ze względu na orientację seksualną, [w:] M. Pawlęga (red.), Przeciwdziałanie dyskryminacji. Pakiet edukacyjny dla trenerów i trenerek. Warszawa: $35-39$.

Salm, M. (2009). „Równe prawa i spokojne życie” - osoby homoseksualne, biseksualne i transpłciowe w Polsce, [w:] K. Remin (red.), Zasady Yogyakarty. Zasady stosowania międzynarodowego prawa praw człowieka w stosunku do orientacji seksualnej oraz tożsamości płciowej. Warszawa: 9-10.

Siuta, J. (2009). Słownik psychologii. Kraków.

Stachura, E. (1987). Opowiadania. Warszawa.

Świerszcz, J. (2011). Badania nad przemoca motywowana homofobia, [w:] P. Szczepłocki (red.), Przestępstwa z nienawiści w Polsce. Publikacja pokonferencyjna. Toruń: 1-3.

Świder, M., Winiewski, M. (2017). Sytuacja społeczna osób LGBTA w Polsce. Raport za lata 20152016. Warszawa.

Polityka (2018). Ucieczka z gorsetu. Polityka 37(3177): 11-11.

Wasik, M., Godzisz, P. (2016). Hate crimes in Poland 2012-2016. Warszawa.

Wieruszewski, R. (2009). Zasady Yogyakarty - geneza i znaczenie, [w:] K. Remin (red.), Zasady Yogyakarty. Zasady stosowania międzynarodowego prawa praw człowieka w stosunku do orientacji seksualnej oraz tożsamości płciowej. Warszawa: 17-20.

Zielińska, E. (2009). Opinia w sprawie projektu zmian kodeksu karnego, [w:] G. Czarnecki (red.), Raport o homofobicznej mowie nienawiści w Polsce. Warszawa: 77-82.

\section{'OTHERNESS IRRITATES UNIFORMITY.' DISCRIMINATION AGAINST LGBT PEOPLE - A FEW REMARKS WITH PARTICULAR EMPHASIS ON THE PROVISIONS OF THE PENAL CODE}

\section{Summary}

Sexual minorities are present in every society. Unlike heterosexual orientation, an LGBT orientation often meets with a lack of acceptance and discrimination. Until 1991, the World Health Organization included homosexuality in the list of diseases. In some countries, the death penalty is the punishment for talking about sexual preferences openly. Discrimination due to sexual orientation 
and gender identity is socially accepted in Poland. The provisions of the Polish Penal Code do not contain effective mechanisms which can protect this group against homophobic hate speech. This often results in distrust with regard to law enforcement agencies and is the reason why many of these cases are not reported. The law should provide protection to every person, regardless of their differentiating characteristics.

Keywords: LGBT; lesbians; gays; discrimination; homophobia; Penal Code 
